views of the prophetic future seem open to criticism. But, as a challenge to the divisive critics to submit their processes and results to the tests applied by men in courts of law and in the business world, this book has a mission. One reviewer found the book so interesting that he read it through at one sitting.

JoHN R. SaMpey.

\title{
The Codes of Hammurabi and Moses.
}

By W. W. Davies, Ph. D. Jennings \& Graham, Cincinnati. Pages 125. Price 75 cents net.

This is easily the most convenient manual on the Code of Hammurabi. The text of the Code is given in Small Pica type, the parallels from the Old Testament in Long Primer, while the author's notes are printed in Brevier type. The book is thus a delight to the eye. Dr. Davies has made good use of the best work of the specialists in Assyriology. He has appended indices that greatly increase the usefulness of the manual. Bible students everywhere ought to have the book.

JoHN R. SAMPEY.

\section{Bible History [Old Testament] after the Results of}

Historical Criticism. Arranged for Students of Different Ages.

By Pastor X. Koenig. Translated from the French by Mary Louise Hendee. 1905, McClure, Phillips \& Co., New York.

In the introduction the author says: "It is the aim of this little book, which we confidently offer to Bible students and teachers, to help restore the Bible to the unique place it ought to hold in every Protestant family; and it is also its aim to testify to the fact, that historical criticism, far from having 'demolished' the Bible, has, by subjecting it to tests used in establishing the validity of other documents of antiquity, eliminated a great part of the difficulties it presents in the face of modern thought, and made it yield up more of its grandeur and significance, as the priceless document of the progressive revelation of God for the salvation of suffering men." In an- 
other connection he remarks: "We recognize the fact that there are myths and legends in the Bible, and we do not fear to acknowledge that it is sometimes difficult, if not impossible, to disengage the true history from the legends in which it is buried. Before this frank avowal, Voltaire is disarmed." The question arises in the mind of the reader whether Voltaire, if he were alive, would care to take up arms against such a naturalistic view of the Bible as this little book presents. Thus the author holds that the narratives of the lives of the patriarchs are absolutely legendary. He would draw moral and spiritual lessions from legendary material, and would explain the presence of such legends in the Old Testament on the ground that our Lord himself used fiction in his remarkable parabolic teachings.

The book contains selections from all parts of the Old Testament Scriptures. In circles in which the Bible is no longer read this little manual might call attention to the charm and beauty of the Scriptures; in circles where the Bible is studied as the priceless Word of God such a book would be absolutely worthless.

John R. Sampey.

\section{An In troduction to the old Testament.}

By John Edgar McFadyen, M. A. Octo., cloth. Pages 356. A. C. Armstrong \& Son, New York, 1905.

For a reasonably brief and attractive presentation of the so-called advanced criticism of the Old Testament we know of no volume that is superior to this work by Prof. MoFadyen. The author avows his chief purpose in the discussion to make an interesting book. In this he seems to have succeeded. On almost every page we have encountered statements which were either questionable or from our point of view manifestly untrue. With the philosophical assumptions at the bases of the book we have little sympathy. It seems to us that for the young minister to begin his study of the Old Testament with this manual as a guide would be exceedingly unfortunate. 